\title{
Assessing the Political and Economic Situation in Belarus: An Awkward Partner Beyond the Enlarged European Union?
}

\author{
Kiryl Haiduk
}

\section{Introduction}

Eastward enlargement of the European Union (EU) and the North Atlantic Treaty Organisation (NATO) will redraw the continental map at a truly historic scale. Accordingly, in the next year Belarus will find itself bordering the enlarged EU, which will encompas the republic's immediate neighbors, such as Latvia, Lithuania, and Poland. This situation poses questions about what kind of risks and opportunities might arise and which policy reactions are needed. Could Belarus and the enlarged EU implement policies that will contain the seeds of efficiency that may sustain "peaceful coexistence" between two neighbors? The answer is far from certain for a a number of reasons. Politically, the country stands far from Brussels-based and other EU institutions in political, economic and ideological terms. As a result, Belarus is often treated as an "outcast" of Europe, the last refuge of authoritarianism, located at the distant periphery of the European transition economies' spectrum. Belarusian economic performance - made up of puzzling economic growth, high inflation, slow industrial restructuring, low investment and permanent pressures to devalue the Belarusian currency - is not very impressive, especially in the light of the dynamic processes of EU enlargement and economic reforms in Central and East European (CEE) transition economies, which have been reshaped by myriad decisions about trade, investment, and foreign aid. As might be tentatively suggested, Belarus could improve its economic performance by using the trade and investment opportunities typically associated with the "widening" of the EU and by synchronizing and catching up with more advanced reformers, including not only Central and East European countries (CEECs), but also the Russian Federation (RF).

The events of September 11 have reformulated the EU policymaking agenda in such a way that various hard and soft security risks have assumed crucial importance. This necessarily implies narrowing down the vision of cooperation to neo-realist "power politics." In contrast, this paper maintains that a somewhat broader perspective should be used when to think about building long-term relationships between the EU and nonaccession countries, including Belarus. The limitations of conventional approaches could be overridden by referring to the importance of domestic social forces as well as coalitions between them, which constitute the groundwork for more intense and dynamic long-term relationships.

The paper concludes that one of the best policy scenarios is the one that treats EU expansion as an excellent window of opportunity to reap significant benefits for Belarus if its policymakers would realize political and economic potential that already exists and would generally agree to adopt a more cooperative stance toward their partners located 
beyond the western border. This idea also lies behind the policy recommendations offered in the conclusion. The paper consists of two parts. The first part deals principally with recent political developments in Belarus, notably foreign policy and relations with the West, where the EU still remains the principal actor. In addition, the paper also briefly touches upon such a sensitive issue as possible repercussions of extending the Schengen acquis. The second part analyzes the economic situation in Belarus, paying attention to foreign economic orientation and integrationist attitudes. Finally, the paper outlines possible scenarios and formulates policy recommendations.

\section{Remarks on the Political Situation Before and After the Second Presidential Elections}

To begin with, we need to shed some light on recent political developments and the social forces that are behind these developments. The 2001 presidential elections provide a vantage point for analyzing the socio-political environment in Belarus because it made the constellations of domestic social forces more salient. According to the conclusions of the International Limited Election Observation Mission (ILEOM) of Organisation for Security and Co-operation in Europe's (OSCE) Office for Democratic Institutions and Human Rights (ODIHR), "with three candidates competing in the presidential elections, voters in Belarus were offered a genuine political choice, although the restrictive campaign regulations and practices made it extremely difficult for the voters to be fully informed about the alternatives" (OSCE/ODHIR Limited Election Observation Mission, 2001 , p. 4) ${ }^{1}$. The criticisms of various international organizations were based on observations of the restrictions imposed by the Belarusian government in order to limit the opposition's access to the state-owned media, such as TV, radio and newspapers. Control over the election campaign had been established to prevent possible interference from international organizations and both international and local NGOs. For instance, political parties were restricted in their ability to include their representatives in the electoral commissions, and a few thousand independent domestic observers had their accreditation revoked. Still, developments in the relationships between the highest government representatives and the opposition are under international scrutiny.

Overall, the 2001 election campaign intensified tensions between two camps of domestic social forces, that is, the government and the opposition. For the opposition representatives, an electoral defeat is counterbalanced by the positive effect of the creation of a unified opposition demonstrated by its putting forward a single candidate. A "civic coalition" has been formed, consisting of the five candidates for the presidency, a Coordination Council of Democratic Forces and the new non-governmental public initiative "For the New Belarus." In other words, the elections have united previously unintegrated political forces, which were able to overcome their differences and thus mature in their political and democratic awareness. This could be considered the most substantial achievement of the Belarusian opposition in terms of strategy, because several tactical mistakes were made and co-operation at the local level was not always coherent and consistent. This is a partial reflection of the fact that the choice of a single candidate was

1 OSCE/ODHIR Limited Election Observation Mission (2001) Republic of Belarus Presidential Election, Final Report, Revised Version, 4 October 2001, Warsaw, http://www.osce.org/odhir/documents/reports/ election_reports/by/bel_sept2001_efr.php3 
made under pressure that the Advisory and Monitoring Group (AMG) of the OSCE (see below) and the USA put on the political parties and social forces.

Further, elections have given an impetus to articulate an alternative vision of development of Belarusian society, a vision which is different from the one persistently defended by the government. Nevertheless, this opportunity has not been used properly. The opposition's electoral campaign was built on criticism of the political regime without offering any clear and convincing argument on what has to be done politically, economically and socially. The absence of policy alternative has to be considered a strategic mistake of the opposition. In addition, the information campaign of the opposition was rather weak. The single democratic candidate headquarters failed to produce a clear message of the campaign that could be repeated by all non-government media. Meaningful contacts with Russian media were not established, which consequently undermined the whole opportunity to raise interest in Belarus in Russia and create information opportunities for Russian TV and newspapers.

After the elections, the major task for the Belarusian opposition remains to maintain and even enhance the degree of unity that was achieved. However, one can hardly observe a substantial improvement here. Opposition forces have returned to the tactics of public protests and demonstrations, traditionally accepted by only a small part of the Belarusian population. The tactics of public protests has been based on considerations of growing dissatisfaction with the worsening economic situation in Belarus and declining popular support for the newly elected president. For instance, the nation-wide survey done by the Independent Institute for Socio-economic and Political Research revealed that the president's approval rating declined from 45 percent in August 2001 to 30.9 percent in April 2002, reflecting the government's failure to orchestrate the process of economic reforms. ${ }^{2}$ Indeed, promises of economic liberalization and relaxation of political control made before the elections have not come to pass. All attempts to acquire a legitimate seat in the Parliamentary Assembly of the OSCE, and the Parliamentary Assembly of the Council of Europe made by the National Assembly have not been successful.

Perhaps what is lacking are efforts to organize a public dialogue between the government and the opposition to promote policy innovations that might combat the dysfunctions of the Belarusian polity and economy. So far, several attempts have been made, all far from being positive. For instance, an initiative from the United Civic Party to discuss the program of systemic reforms and the "Concept of the Budgetary Reform in Belarus and Guidelines for the Budget of 2002" among a group of independent experts and government representatives failed. As for the lobbying groups and various employers' associations, they are quite weak in influence on either public opinion or the policy process. The Belarusian Union of Entrepreneurs and Employers does not have any serious influence over the decision-making process in spite of the fact that its head, Tamara Byikova, chairs the Presidential Council on Entrepreneurship. All other organizations, such as the Union of Entrepreneurs or the Union of Industrialists and Entrepreneurs are also unable to exert any meaningful influence over the course of societal development. Therefore, it is hardly possible to talk about a lobby which could counterbalance the policies of the Belarusian government.

In such a situation, a promising strategy might be to rely on the emerging civil society because its growth signifies the people's increasing awareness about the necessary preconditions for development. According to the registration data provided by the Min-

2 www.praca.by 
istry of Justice, there are about 2,500 non-governmental organizations in Belarus. These organizations function in a variety of fields, from reconstruction of history to environmental protection, charity, education and research. However, NGOs operate under governmental pressure. Presidential Decree No. 8 establishes control over donations to the third sector, thus making it problematic for the non-governmental sector to accept material help and various grants. Recently, the government has even tried to establish control over sociological surveys which are allowed only after permission is obtained from the relevant state body. ${ }^{3}$ All of these regulations prevent civil society from growing.

\section{Uneasy Relations With the EU Emissaries: A Crisis Ahead?}

The relationship between Belarus and EU structures could be labelled as protracted and uncertain. Hopes, often expressed by the EU bodies, are often undermined by illogical and even hostile reactions from Belarusian authorities. To begin with, the relationships between the EU have been institutionalized in 1994 when the Partnership and Cooperation Agreement (PCA) was signed. At present, the Agreement no longer serves as a guide to cooperation because the Council of Europe (CE) embargoed all high-level political cooperation in January 1997. The reason for the embargo is the fraudulent referendum of November 1996, when several amendments to the original version of the Belarusian Constitution were made. These amendments have allowed a significant extension of presidential power and at the same time restricted the role of the Parliament. The EU nonetheless has retained its presence in Belarus through the "troika," consisting of the representatives of the Parliamentary Assembly (PA) of the Organisation for Security and Cooperation in Europe (OSCE), the Council of Europe, and the European Parliament (EP). The primary goal of the troika has been to coordinate policies of various EU bodies towards Belarus to avoid unnecessary competition among them. Moreover, such a joint body has been rather successful in overriding a certain degree of discord that exists among the EU member states in relation to Belarus.

Fundamentally, the speed and scope of Belarus' political cooperation with the (Western) European structures is determined by its domestic socio-political developments in the areas of human rights, media and democratic representation. According to most observers, Belarus is currently building an authoritarian political regime, in which the president always has the final word in the policy process. As a result, the division of powers is disregarded, which has been institutionalized with the referendum of November 1996. Since that time, Belarusian authorities have demonstrated persistent stubbornness in relaxing domestic norms and regulations in accordance with the democratic principles formulated by the CE in 1998. Those principles are known as "Istanbul criteria" because they were proposed jointly by the Parliamentary Assembly of the Council of Europe (PACE) and the EP at the OSCE summit held in Turkey. The overall meaning of these criteria is to bring about changes in Belarusian law in such areas as media, parliament, electoral procedures, and also to create a public dialogue between opposition forces and the government. Formally, meeting the Istanbul criteria automatically leads to a renewal of a special observer's status at the PACE for the lower chamber (Chamber of Representatives) of the Belarusian Parliament, which it lost in January 1997. So far, almost no progress has been achieved on meeting these requirements.

3 www.svaboda.org 
First, changes in the electoral law, allowing opposition parties and their leaders to promote their views publicly, have not been made. The draft of this law has not even been submitted to the CE's expert commission. Second, in spite of several promises, the opposition has not been granted direct and open access to the state-owned television and newspapers. Several independent media (such as the newspaper Pahonya) were closed by the government because there were judicial procedures initiated against them. Third, the National Parliament still has relatively weak influence over the domestic political process. Several important laws, notably on human rights protection and on the creation and function of an "Ombudsman," have not even appeared on the parliamentary agenda, except during a one-day session on human rights. Fourth, a period of peace and mutual trust between the government and the opposition has not been kept for long despite the insistence of the PACE. Opposition leaders and political activists have been brought into courts for organizing pickets and demonstrations. The militia has been quite brutal in fighting with participants of demonstrations that are organized by the opposition. Recently, there have been attempts to create a "controlled" opposition by way of reorganizing trade unions to support the pro-government trade unions at large industrial enterprises. The process of opening up of a non-governmental organization (NGO) is complicated and entails time-consuming registration procedures. The state is very often hostile to NGOs, which are blamed as the protagonists of Western influence.

As it might be seen from the analysis above, the Istanbul criteria, which could be considered as a "pass" for Belarus to Europe, are still far from being fulfilled, and there is little evidence that this course of events will be changed in the near future. Various assessments of the political and economic situation, produced both by the PACE and the PA of the OSCE basically share this point. Ultimately, not a single law on which the EU insists changes should be made has been amended. For instance, in January 2001, speakers from the Chamber of Representatives shocked the members of the PACE when presenting a draft of the information security law. The draft exerted a sharp critique of "aggressive promotion of western values as the ultimate truth through the media by using aggressive journalist tools."

In the words of Adrian Severin, the head of the OSCE's PA and the head of the Working Group on Belarus, there have been plenty of opportunities for democratization in Belarus, which could help it to restore friendly relations with the EU, but none of them have been ever used. ${ }^{5}$ One direct consequence of such uncooperative policies adopted by the Belarusian side is that the position of the EU - and especially the CE remains quite tough in relation to Belarusian official bodies.

Another crucial area for the EU to monitor progress is human rights protection. Finally, the parliament should play a much more active role in preparing and adopting new legislation. Unfortunately, during the last year, the Belarusian parliament has not managed to make itself into a consolidating force passing major reform legislation, which happened in Ukraine in 2001. ${ }^{6}$ All of these spheres of reform should remain on the EU's policy agenda towards Belarus, because they are the landmarks of democratization of the Belarusian society. Sadly, so far Belarus has not made any progress in this direction. One of the greatest problems is the lack of critical reporting, because the state effectively controls both television and the press, while the use of internet as a source of al-

\footnotetext{
Belorusskaya Gazeta, 29 January 2001

Belorusskaya Gazeta, October 15, 2001

6 see: Mildner, in this volume
} 
ternative information is used only by one per cent of the population, of which students from Minsk-based universities make up the largest share.

Recently, there have been attempts to change the set of criteria by inserting and adding more weight to the abolition of death penalty and granting more power to the parliament. Several top functionaries from the Council of Europe mentioned in April 2002 that Belarus could get back its observer's status at the PACE in the coming year if the death penalty were abolished and the parliament would play a more active role in the policy process. ${ }^{7}$ These requirements are undoubtedly important, but they should not be substitutes for the Istanbul criteria. This is related to the fact that some democratic forces both in Belarus and Russia are generally in favor of keeping the death penalty because this step might not be accepted by the general public, which is keenly aware of combating crime. If the Belarusian position with regard to democratization remains stubborn and does not change, this could lead to a worsening of the situation and curtailing contacts between the Belarusian government and the EU. As for the situation with the OSCE's PA, this body has generally adopted a more cooperative stance toward Belarus, and this became clearly visible since the Berlin session held in July 2002. In February 2003, the Belarusian parliament was finally granted membership status at the OSCE Parliamentary Assembly. Apart from some procedural peculiarities that helped this decision to be adopted, reopening the OSCE office in Minsk definitely played a catalyst's role.

\section{OSCE Versus Belarus: The End to Perpetual Conflict?}

Until the end of 2001, the AMG of the OSCE, headed by Ambassador H. Wiek from Germany, had been playing a rather positive instrumental role in helping Belarusian authorities to translate the CE's 'Istanbul criteria' into domestic law. Unfortunately, the group has not succeeded in its goals. Numerous attempts to organize a meaningful public dialogue between the government and the opposition forces had failed so that the group has eventually turned to support the opposition camp, where it has definitely gained a decent degree of authority. The AMG has indeed contributed to the formation of civil society in Belarus by promoting a dialogue between political parties and various NGOs, which otherwise would have remained unintegrated. Apparently, these activities at the civil societal level have generated a rather negative reaction from the Belarusian authorities. Ultimately, Ambassador Wiek was named by the head of Belarusian KGB as a "spy of the West". He had not been even allowed to come back to Belarus for a private visit. Further, Belarusian authorities have simply blocked the appointing of a new head of the mission. In May 2002, Belarusian authorities had not extended visas for two diplomats working for the OSCE. According to Uta Zapf, the head of the OSCE PA's Working Group on Belarus, this conflict marked a significant discrepancy in opinions between the Belarusian authorities and the OSCE. ${ }^{8}$

On a more practical side, the Ministry of Foreign Affairs insisted on the revision of the field mission's mandate because its activity so far has been destructive and unhelpful, not corresponding to its original goals. At the beginning not a single concrete pro-

7 Belorusskaya Gazeta, January 29, 2002

8 Belorusskaya Gazeta, May 5, 2002 
posal was offered from the Belarusian side on what should be changed in the mission's mandate. All proposals were limited to uncertain and abstract rhetoric, with only one clear statement that "the mandate should be changed." At the beginning of June 2002, it was still unclear whether the group would function in Belarus at all. The AMG office was closed de facto on 29 October 2002, a month after negotiations between Belarus and the OSCE began in Vienna. They ended in passing a new mandate and signing a new Memorandum of Understanding. As Ambassador Eberhard Heyken said in his statement, an outcome achieved is "absolutely in conformity with the OSCE rules and principles." 9 The new mandate includes two new areas, notably economy and environment, apart from more customary tasks such as protection of human rights. These new tasks generally reflect the new understanding of security, as formulated in the European Security Charter adopted by the OSCE Summit in Istanbul in November 1999. The economic and ecological dimensions of security were also addressed in May 2003 in Prague at the OSCE annual economic forum, where the Belarusian delegation discussed the issues of illegal migration and drug trafficking, and found this dialogue quite useful for further cooperation. ${ }^{10}$

The end of the conflict between the Belarusian authorities and the OSCE can be considered a positive outcome, because the AMG represents the only meaningful link that bridges the gulf between officials in Minsk and officials in Brussels and Strasbourg. The group has not retreated from Belarus, implying that there is scope for organizing a dialogue between authorities and domestic social forces that are progressively oriented toward a more liberal development model. Indeed, European bodies as well as NGOs might play an important role in constructing a frame for dialogue between opposing groups, thus enhancing stability and democracy in the country. There is a need for the EU to devise coherent policy measures towards Belarus. This what the EU is doing at present.

In March 2003 the European Commission adopted a new framework for relations over the coming decade with countries that do not currently have prospects of membership, but which will soon find themselves bordering the enlarged EU. This framework offers all the neighboring countries a stake in the EU's internal market as soon as they demonstrate "shared values and effective implementation of political, economic and institutional reforms." 11 Therefore, Belarus has been offered an opportunity to join the enlarged EU's "ring of friends." If Belarus accepts this chance to improve its relationships with the EU, it can definitely gain from better access to the single market, intensified cooperation to prevent security threats (such as illegal migration), new instruments for investment promotion and support for integration into the global trading system. The latter might be of a special importance for Belarus, which is currently negotiating WTO membership.

But Belarus inevitably should make some steps on its own. This concerns, for instance, improving the regulatory framework for accepting foreign technical aid, to benefit from technical assistance programs such as TACIS. The experience with the OSCE conflict teaches us that the EU should implement a common strategy on Belarus if a

9 Statement by Head of OSCE Office in Minsk, Ambassador Eberhard Heyken Press Conference, Monday, 17 February 2003

10 Izvestia, May 22, 2003, p. 3

11 Wider Europe - Neighbourhood: proposed new framework for relations with the EU's Eastern and Southern Neighbours, IP/03/358 - Brussels, 11 March 2003, http://europa.eu.int/comm/external_ relatiosn/we/intro/ip03_358.htm 
positive reaction from the country is recorded. Only in this case the EU can step in and update the list of cooperation activities with the aim of focusing bilateral relations on implementing strategic priorities.

\section{Repercussions of a New Border Regime}

Crucially, it is impossible to ignore Belarus because of its unavoidable location-right in the Middle of Central and Eastern Europe, the geographic heartland of what in German is called Mitteleuropa. In such a connotation, the country might be perceived as a bridge between the enlarged EU and Russia, and between the Baltic Sea region and Ukrainian lands. In the context of post-Cold War Europe, this bridge could hardly be kept blocked. Borderlands should not mean new walls, demarcating pro-European and pro-Russian camps, and the integrative pan-European attitude must be preserved.

Hence, it appears that the next important area that the EU should consider is the border regime and the repercussions of extending the Schengen acquis. Nowadays, one of the unquestionable achievements of the 1990s, the freedom of travel between Eastern Europe and Central Europe, is seriously endangered. EU enlargement will inevitably erect a new border in the East, that is, between the countries incorporated into the EU and those remaining outside. For the EU, the task is therefore to establish friendly relationships with one of the its immediate eastern neighbours, such as Belarus. An irrevocable adoption of the Schengen acquis could complicate cross-border contacts and undermine the attitudes towards mutual cooperation. In the short run, adoption of the tough Schengen acquis could affect thousands of ordinary citizens on both sides of the border. This step may even deepen the historic trail of mutual prejudice, stereotypes and resentment that exists among CEECs. For Poland, maintaining an open border policy with Belarus has been a part of a wider policy of securing good relationships with its immediate neighbor, which has a sizeable Polish minority. Moreover, the introduction of a fully-fledged visa regime for Belarusians by the Polish side could easily result in an almost complete loss of cross-border trade in an already economically depressed region. Aware of these negative repercussions, the Polish authorities agreed to keep visa fees as low as possible and to make the process of obtaining a visa as easy as possible. However, one can imagine a whole range of measures to counterbalance these negative consequences, both real and perceived. ${ }^{12}$ In the long term, the most feasible solution is to abolish mandatory visa procedures and introduce of other forms of registration, for instance at the borders. If existing attitudes about building a cordon sanitaire of new members from the CEE periphery are further strengthened, EU enlargement could be perceived as a threat from the West, a process, associated with marginalization and exclusion, an obstacle for thousands of ordinary citizens. Overall, the imposition of restrictive principles for crossing the borders will contribute to widening developmental gaps in politics and economics. These gaps are most vividly seen when one observes progress in economic transition across the region.

12 see policy recommendations in Boratynski, J. \& Gromadzki, G. 2001, and also: Mildner in this volume 


\section{Principal Features of the Belarusian Economic System}

What kind of economic system is Belarus trying to build within its borders? According to the policy document "Major Trends in the Social and Economic Development of the Republic of Belarus in 1996-2000," the country officially adopted the target model of "the socially oriented market economy." The term has been defined as a competitive market economy with mixed private and state ownership, and an extensive use of social welfare policies, such as keeping a high employment rate and maintaining social safety nets. Although use of the word "social" may remind one of a German-style social market economy model, in practice its characteristic features in Belarus evoke various interventionist regimes similar to the East Asian developmental states, albeit without the degree of success they have achieved. In the literature on transition economies, Belarus has conventionally been considered as an apparent laggard in transformation process and accordingly labelled as a "command economy without central planning." 13 Indeed, the Belarusian economic system can be characterised as an old-fashioned, very much "Sovietised" attempt to reconcile the state and the market, with the heavy domination of the former. I will explore this argument in detail below by invoking the characteristic features of Belarusian economy.

The central element of the transformation process in the former Soviet bloc has been the extension of private sector activity. According to the European Bank for Reconstruction and Development, Belarus has been demonstrating a low and falling rating in the past four years in terms of the extension of private economic activities. ${ }^{14}$ In the year 2000 , the republic had the lowest private sector share of GDP among post-Soviet and other transition economies.

Table 1. Private Sector Share of GDP, percent ${ }^{15}$

\begin{tabular}{lrccccccccc}
\hline Country & 1991 & 1992 & 1993 & 1994 & 1995 & 1996 & 1997 & 1998 & 1999 & 2000 \\
\hline Albania & 5 & 10 & 40 & 50 & 60 & 75 & 75 & 75 & 75 & 75 \\
Belarus & 5 & 10 & 10 & 15 & 15 & 15 & 20 & 20 & 20 & 20 \\
Bulgaria & 20 & 25 & 35 & 40 & 50 & 55 & 60 & 65 & 70 & 70 \\
Czech Republic & 15 & 30 & 45 & 65 & 70 & 75 & 75 & 75 & 80 & 80 \\
Estonia & 10 & 25 & 40 & 55 & 65 & 70 & 70 & 70 & 75 & 75 \\
Hungary & 30 & 40 & 50 & 55 & 60 & 70 & 75 & 80 & 80 & 80 \\
Latvia & 10 & 25 & 30 & 40 & 55 & 60 & 60 & 65 & 65 & 65 \\
Lithuania & 10 & 20 & 35 & 60 & 65 & 70 & 70 & 70 & 70 & 70 \\
Moldova & 10 & 10 & 15 & 20 & 30 & 40 & 45 & 50 & 45 & 50 \\
Poland & 40 & 45 & 50 & 55 & 60 & 60 & 65 & 65 & 65 & 70 \\
Romania & 25 & 25 & 35 & 40 & 45 & 55 & 60 & 60 & 60 & 60 \\
Russia & 5 & 25 & 40 & 50 & 55 & 60 & 70 & 70 & 70 & 70 \\
Slovak Republic & 15 & 30 & 45 & 55 & 60 & 70 & 75 & 75 & 75 & 80 \\
Ukraine & 10 & 10 & 15 & 40 & 45 & 50 & 55 & 55 & 55 & 60 \\
\hline
\end{tabular}

Private sector developments have been aggressively militated by the omniscient presence of the state and its various supervising and controlling bodies, which often demonstrate predatory behavior towards the private activity. So far the country has been avoiding such measures as massive privatization (even in the small- and medium-size enterprise sector) as well as substantial reorientation in the country's foreign trade pat-

13 IMF, 1999

14 EBRD, Transition Report 2000/2001

15 EBRD, Transition Report 2000/2001 
terns. The situation in the Belarusian economy is similar to the time of the collapse of state socialism in the former Soviet Union, where state-owned property exceeded twothirds of all assets. ${ }^{16}$ The degree of state vs. market hybridity manifests itself in the persistence of quasi-monopolies in key sectors and significant price controls. ${ }^{17}$ For instance, decree No. 591 of 1997 opened the possibility of maintaining state control over privatized enterprises through retention of a so-called "golden share," which allows the state to intervene at any time and block the functioning of the private enterprise. The strategic orientation, in which Belarusian government persistently believes and tries to implement, is to rely upon unreformed and poorly modernized large industrial enterprises, which earlier served as Fordist-type assembly shops of the former Soviet Union. Direct subsidization of various enterprises, which are often considered "strategic" for the national economy, through the state-controlled credit allocation system, along with an attempt to direct their output towards the once-again "strategic Russian market, have proved to be the long-standing features of the Belarusian "growth miracle," manifested in the relatively impressive dynamics of output recovery and economic growth compared to the republic's immediate neighbors.

Table 2. Rates of Growth of Real GDP, Annual Percentage Change, 1993-2002 ${ }^{18}$

\begin{tabular}{lrrrrrrrrrr}
\hline Country & 1993 & 1994 & 1995 & 1996 & 1997 & 1998 & 1999 & 2000 & $\begin{array}{c}2001 \\
\text { est. }\end{array}$ & $\begin{array}{c}2002 \\
\text { proj. }\end{array}$ \\
\hline $\begin{array}{l}\text { Transition } \\
\text { economies }\end{array}$ & -8.9 & -8.6 & -1.5 & -0.5 & 1.6 & -0.8 & 3.6 & 6.3 & 4.0 & 4.1 \\
CEE & -0.3 & 3.0 & 5.6 & 3.9 & 2.5 & 2.3 & 2.0 & 3.8 & 3.5 & 4.2 \\
CIS and Mongolia & -12.6 & -14.6 & -5.5 & -3.3 & 1.0 & -2.8 & 4.6 & 7.8 & 4.4 & 4.0 \\
Belarus & -7.0 & -12.6 & -10.4 & 2.8 & 11.4 & 8.3 & 3.4 & 5.9 & 2 & na \\
Latvia & -14.9 & 0.6 & -0.8 & 3.3 & 8.6 & 3.9 & 1.1 & 6.6 & 4.75 & na \\
Lithuania & -16.2 & -9.8 & 3.3 & 4.7 & 7.3 & 5.1 & -3.9 & 3.3 & 3.5 & na \\
Poland & 4.3 & 5.2 & 6.8 & 6.0 & 6.8 & 4.8 & 4.1 & 4.1 & 4 & na \\
Russia & -13.0 & -4.2 & -3.4 & 0.9 & -4.9 & 5.4 & 3.3 & 8.3 & 4.0 & 4.0 \\
Ukraine & -14.2 & -22.9 & -12.2 & -9.8 & -3.3 & -1.9 & -0.2 & 5.8 & 2 & na \\
\hline
\end{tabular}

Belarus has managed to achieve decent rates of both GDP growth and industrial gross output much faster than the other former Soviet republics, but these have foundered with the resumption of two-digit inflation rates what become a historic experience in almost all transition economies. For instance, in the year 20006 percent economic growth was countered by 150 percent inflation, while for transition economies these figures were 5.3 and 19.6 per cent, and for the CIS economies, 6.4 and 24.8 per cent, respectively. The problem here is that Belarusian government is trying to adopt barely possible sets of policy targets: non-inflationary growth and large-scale subsidies; balanced budget and cheap directed credits; high savings and low nominal interest rates that are even negative in real terms; current account balance and multiple official exchange rates, administratively fixed at a stable but increasingly overvalued rate. These policies have proved to be inconsistent and devastating, and their application in further practice can only be inefficient and costly, and, if persistent, can even ruin the Belarusian economy. For instance, special treatment of large industrial entities through subsidization and wage increases has produced high inflation rates instead of improvements in the quality of goods or rising export volumes. Ex-

16 Zlotnikov, L. 1999

17 IMF, 1999

18 IMF, 2001, pp. 195, 205; * data obtained from ECE, 2002, World Economic Situation and Prospects, p. 16 
pansionary wage policy is the second source of inflation, because 30 percent wage increases in 2001 compared to 2000 have not supported by productivity growth, measured by labor and/or total factor productivity.

Table 3. GDP Dynamics, Industrial Output Growth and Price Indexes, Annual Percentage Change ${ }^{19}$

\begin{tabular}{|c|c|c|c|c|c|c|c|c|c|c|c|}
\hline \multirow[t]{2}{*}{ Indicator } & \multirow[t]{2}{*}{1992} & \multirow[t]{2}{*}{1993} & \multirow[t]{2}{*}{1994} & \multirow[t]{2}{*}{1995} & \multirow[t]{2}{*}{1996} & \multirow[t]{2}{*}{1997} & \multirow[t]{2}{*}{1998} & \multirow[t]{2}{*}{1999} & \multirow[t]{2}{*}{2000} & \multicolumn{2}{|c|}{2001} \\
\hline & & & & & & & & & & Q1 & Q2 \\
\hline $\begin{array}{l}\text { GDP at constant } \\
\text { prices }\end{array}$ & -9.6 & -7.6 & -12.6 & -10.4 & 2.8 & 11.4 & 8.4 & 3.4 & 5.8 & 2.2 & 4.8 \\
\hline $\begin{array}{l}\text { Industrial gross } \\
\text { output }\end{array}$ & -9.4 & -10.0 & -17.1 & -11.7 & 3.5 & 18.8 & 12.4 & 10.3 & 7.8 & 2.2 & 6.1 \\
\hline $\begin{array}{l}\text { Consumer prices } \\
\text { (annual average) }\end{array}$ & 971 & 1,19 & 2,22 & 709 & 53 & 64 & 73 & 294 & 169 & & la \\
\hline $\begin{array}{l}\text { Producer prices } \\
\text { (annual average) }\end{array}$ & 1,94 & 1,54 & 2,17 & 462 & 34 & 88 & 72 & 356 & 186 & & la \\
\hline
\end{tabular}

The high employment goal, while flawless character in policy terms, has been largely obtained at the expense of efficiency. Policies aimed at maintaining production for the sake of production have simply lowered national income, because they have piled up unsaleable inventories, often traded either domestically or internationally on unfavorable terms through disadvantageous barter. Production for the sake of production and the rise of industrial output have led to massive inventories in some sectors. Overall, inventories in industrial goods climbed to almost 70 percent of monthly production in June 2001, from 60 percent in January 2001. Domestic barter transactions at the end of May 2001 accounted for almost 50 percent of GDP compared to 40 percent in early 2000 (see table below).

Table 4. Inventories of Final Products in the Warehouses of Industrial Enterprises by

\begin{tabular}{lrrrrrrrr}
\multicolumn{7}{c}{ Selected Sub-sectors, as a Percentage of the Current Month's Output ${ }^{20}$} \\
\hline Sector/year & 1996 & 1997 & 1998 & 1999 & 2000 & \multicolumn{2}{c}{2001} \\
& & & & & & Q1 & \multicolumn{1}{c}{ Q2 } \\
\hline Total & 69.4 & 55.9 & 85.9 & 54.7 & 62.8 & 60.3 & 67.9 \\
Machine-building and metal-working & 157.8 & 122.6 & 145.7 & 93.9 & 104.2 & 102.7 & 122.8 \\
Light industry & 69.7 & 54.7 & 110.8 & 71.5 & 101.5 & 99.3 & 114.6 \\
Construction materials industry & 67.7 & 48.3 & 59.4 & 44.7 & 72.3 & 74.2 & 74.7 \\
Forestry, wood and paper products & 59.9 & 39.1 & 79.9 & 51.4 & 82.0 & 79.3 & 87.7 \\
\hline
\end{tabular}

Another negative feature, which has emerged as a consequence of the policy of maintaining output at any price, is the growth of loss-making enterprises.

19 EBRD Transition Report Update, April 1999; IMF, 2002

20 IMF, 2002, p. 78 
Table 5. Share of Number of Loss-Making Enterprises in Selected Sectors, in Percent $^{21}$

\begin{tabular}{lrrrrrrr}
\hline Sector/year & 1996 & 1997 & 1998 & 1999 & 2000 & & 2001 \\
& & & & & & Q1 & Q2 \\
\hline Total economy & 18.4 & 12.3 & 16.2 & 16.9 & 23.4 & 40.1 & 35.8 \\
Industry & 17.6 & 11.8 & 10.5 & 8.8 & 18.8 & 33.6 & 32.0 \\
of which & & & & & & & \\
Petrochemicals & na & na & 10.0 & 12.5 & 75.0 & 42.9 & 28.6 \\
Machine-building & 13.4 & 8.2 & 8.0 & 7.4 & 16.5 & 25.8 & 24.8 \\
Wood and paper & 9.1 & 7.7 & 8.3 & 8.0 & 16.7 & 27.9 & 33.7 \\
Construction material & 33.8 & 24.4 & 22.0 & 19.9 & 35.3 & 57.1 & 52.1 \\
Light industry & 39.0 & 22.2 & 15.5 & 13.1 & 28.6 & 98.2 & 49.0 \\
Food industry & 9.8 & 7.5 & 5.4 & 2.9 & 12.2 & 34.9 & 25.9 \\
\hline
\end{tabular}

What may seem puzzling and even paradoxical in this situation is how the Belarusian economy has managed to achieve relatively high growth indicators of its GDP by more 30 percent between 1996 and 2000. According to one of the estimates, policies of economic integration into the Russian market have contributed about 2.3 percent of growth each year. ${ }^{22}$ Perhaps external economic policies adopted by the Belarusian government can serve as an explanation of this phenomenon. This thought is explored in the next section.

\section{Belarus' External Economic Policies and Integrationist Attitudes}

Since the collapse of the Soviet economic system, Belarus has remained strongly oriented towards the CIS and especially the Russian market, very often at the expense of participation in Western markets. The Belarusian government has chosen the Russian Federation as the key partner in both the economic and political spheres, thus trying to link the Belarusian market to the arguably prosperous Russian economy. Indeed, the success of small open economies is often dependent on the degree of their embeddedness into the flourishing regional economy or the intensity of exchange linkages with the dominant foreign economic partner. This in turn shapes the modernization process, which in the context of European transition economies implies the adjustment of the national economy to the requirements of European, and world, markets in the course of long-term adoption of Western (European) economic and socio-political structures. In other words, the internationalisation of European transition economies, which in practice has meant export reorientation towards Western markets and subsequent incorporation into the production networks of Europe-based transnational corporation (TNCs), is an intrinsic part of the transformation process. Nonetheless, this has not become the case in Belarus. In Belarus, opening up toward the global market has been constrained by internally articulated causes because the government has believed that the intervention of foreign capital may jeopardize political independence and the decision-making autonomy. Overall, external economic orientation has not been changed dramatically over the

21 IMF, 2002, p. 89

22 Nuti, M., 2000, pp. 45-79 
last ten years, so that the economic relationship between Belarus and the EU and the accession countries seem not to be very active, especially compared to the evolving intensity and dynamism of economic linkages further west. Germany and Poland account for no more than 4 percent of the republic's export, while Latvia and Lithuania have gradually assumed their place in Belarus' foreign trade turnover. As can be seen from the table below, Russia has proved to be the key partner both, by the integration agreements signed and the actual patterns of economic integration.

Table 6. Export Orientation of the Republic of Belarus 1996-2001, percent ${ }^{23}$

\begin{tabular}{lrrrrrr}
\hline & 1996 & 1997 & 1998 & 1999 & 2000 & 2001 \\
\hline Russia & 53.5 & 65.5 & 65.2 & 54.5 & 50.7 & 53.05 \\
Ukraine & 8.5 & 5.8 & 5.5 & 4.7 & 7.6 & 5.7 \\
Other CIS states & 4.6 & 2.4 & 2.3 & 2 & 1.8 & 1.5 \\
Germany & 3.5 & 3 & 2.8 & 3.6 & 3.2 & 3.2 \\
Poland & 6 & 3.4 & 2.6 & 3.5 & 3.4 & 2.5 \\
Latvia & 3.4 & 1 & 2.4 & 4.4 & 5.2 & 5.8 \\
Lithuania & 2.6 & 1.9 & 2.2 & 3 & 4 & 2.5 \\
Other non-CIS & 18 & 17 & 17 & 24.3 & 24.2 & 20.6 \\
\hline
\end{tabular}

Table 7. Share of CIS in the Gross Volume of Exports and Imports of Belarus, Percent $^{24}$

\begin{tabular}{lrrrrrrrr}
\hline Indicator/Year & 1994 & 1995 & 1996 & 1997 & 1998 & 1999 & 2000 & 2001 \\
\hline Exports & 58.9 & 63.2 & 68.6 & 73.7 & 73 & 61.3 & 60.4 & 65.4 \\
Imports & 68.2 & 66.1 & 65.9 & 66.9 & 65.0 & 64.3 & 70.8 & 71.9 \\
\hline
\end{tabular}

Still, Russia remains Belarus' largest trading partner, accounting for t53 percent of exports and 67 percent of imports during the first six months of 2001. Such patterns of economic integration cannot be solely ascribed to political measures. Rather, they originated in 1992-1995, when economic integration with Russia contained the seeds of economic efficiency, which had been based on two factors. First, the policy of price controls aimed at keeping inflation rates in Belarus low had forced national producers to search for more profitable export markets. They had been found in Russia, which soon became the primary destination for Belarusian exports. Crucially, price differentials between two countries had nurtured economic exchange because the partners adopted different value-added tax (VAT) rates, while leaving relatively low formal control over foreign trade. Second, several agreements between Belarus and Russia had secured preferential access for Belarusian goods to the Russian market and also allowed Belarus to obtain necessary energy resources for enterprises at fixed prices, which in turn sheltered them from the painful economic restructuring proceeding at that time in CEECs. Foreign trade with Russian had further expanded due to the depreciation of the Belarusian currency with respect to the Russian rouble, signing of customs union agreement, and direct central "exhortations" to export even on unattractive terms, on credit, or for barter. Still, in 2001, 30 percent of Belarusian goods to the Russian Federation were sold through barter schemes, while another 6 percent are goods made on commission, resembling the OPT-type exchange between the EU and CEECs. ${ }^{25}$ One of the direct consequences of such trade expansion policies is that Belarusian goods are traded by Russian dealers because they have been obtained at cheaper prices through barter operations with energy

23 Ministry of Statistics and Analysis of the Republic of Belarus

24 Author's calculations, based on UNECE, 2001, p. 171, Ministry of Statistics and Analysis

25 Belorusskaya Gazeta, March 4, 2002, p. 8 
resources. This has created a paradoxical situation in which Belarusian exporters can not sell their goods abroad because market access has been blocked by Russian dealers.

The overwhelming dependence on Russian and "near-abroad" suppliers for components and markets for sale of the industrial goods have further strengthened the belief that the economic survival of Belarus depends on the resurrection of economic ties with the Russian Federation. In public opinion, integrationist initiatives have been supported because they were perceived as attempts to reconcile artificially separated economic units and thus resurrect broken economic linkages. For the governments, the task was to conclude integration agreements, and in this realm the Belarusian government soon become the major protagonist. Various integration initiatives (such as customs union, monetary union, confederation, federation, or even union state) have been presented as a panacea for the country's economic woes. At the end of 1999, the two countries agreed to create a union state, providing, inter alia, for the adoption of common tax and customs policies and the establishment of supranational political institutions, such as a Council of Ministers and a parliament. State bureaucrats, feeling nostalgic about the economic power of the former USSR, high-ranking military officers, alarmed about NATO's eastward expansion, enterprise managers involved in bilateral trade and obtaining funds from joint "union" programs (such as a "union TV set" and supercomputer) all belong to the integration advocates' camp. Despite the strong integrationist rhetoric about bringing two brotherly nations together, this fraternal alliance is far from being built on equal relations between two countries. The final unification of customs duties in accordance with Russian law (with exception of approximately 300 positions left different) is an overt illustration of the typical relationships. This is related to the fact that no serious political actor in Russia, except perhaps right-wing liberals, ever advocated the Commonwealth of Independent States (CIS) as a union of judicial equals, as the EU is. Sergei Karaganov, the head of the Russian Council on Foreign and Defense Policy, believes that the relationship between Russia and the CIS should be modelled upon that pursued by the US during the 1950s and 1960s in Central and Latin America. He argues that "The CIS countries could serve as supplies of cheap labor and cheap goods to the Russian economy, creating a circle of dependent states around its perimeter, where Russia would play a dominant economic role." ${ }^{26}$ For Russian politicians, Belarus has very often been treated as important in geopolitical, neo-realist terms, that is, a defendant of Russia's western flank (whose defence is claimed by the Belarusian president to cost $\$ 1$ billion a year, which is a good bargaining chip in negotiations with Russia), and also a reliable transit route to the West. Approximately 70 percent of all export-import flows between Russia and European countries are transported through Belarusian territory each year, which brings in transport service revenues for Belarusian economic agents of close to $\$ 1$ billion per year. ${ }^{27}$

Nevertheless, it seems doubtful whether a one-dimensional integrationist attitude towards the major Eastern partner can bring about the modernization necessary for the Belarusian economy. In fact, Belarus has been experiencing a loss of external competitiveness. According to the most recent IMF observations, made on the basis of the movements of various external real effective exchange rates, Belarus may have lost ground relative to its western competitors and trading partners. ${ }^{28}$ Russian-Belarusian integration is far from being impressive in qualitative terms, e.g. in mutual investment and more sophisticated, in-

26 Karaganov, 1997, p. 299

27 Belorusskaya Gazeta, November 16, 2001, p. 10

28 IMF, 2002 
tra-industry trade. All of these features become salient in the light of the evolving dynamism and intensity of the trade and production networks growing between the EU and the accession countries, including Belarus' immediate neighbours.

\section{Contrasting Cases of EU Enlargement and Russian- Belarusian Integration}

Contemporary international economics emphasizes that for a small open economy, outward orientation with a diversity of linkages and competitive sectors is a good guide to sustained economic progress in the face of external disturbances. Small open economies are simply not large enough to generate economies of scale for the myriad consumption items desired by modern consumers. Thus, these economies rely heavily on export markets to purchase their goods, and import markets to supply their needs. Accordingly, such export-dependence places a special emphasis on maintaining a country's competitiveness. In a system that is so export driven, the key question is whether a country can compete internationally. Maintaining strong performance in these economies requires that their costs remain lower (or productivity levels higher) than their main competitors. ${ }^{29}$ European transition economies, which are almost all small- and medium-sized, have attempted to avoid the deficiency of their size by linking themselves to the EU market. This integrationist attitude has brought significant qualitative developments, related to the complementary production strategy, which is the specific organization of low-cost skilled work to create distinctive industrial capacities. This developmental strategy involves the transfer of significant technological capabilities to host countries. Interfirm linkages create a trajectory that allows local subsidiaries and locally-owned suppliers to move up the value added production chain, resulting in economic dynamism and beneficial spillovers for host countries. As a result of more planned activities of European and global TNCs, the Czech Republic, Hungary, Poland, Slovakia and Slovenia now have an internationally competitive automotive supply industry, and Hungary and Estonia an emerging information technology industry. ${ }^{30}$ By now, the empirical evidence suggests that ongoing organizational experimentation is underway, generating networks in Europe to go beyond simple outward-processing traffic arrangements (OPT), which is the most primitive form of intra-industry trade, toward more sophisticated, technology-based patterns of cooperation. The leaders in this development process, based on intra-industry trade and growing investment, are Hungary and the Czech Republic, with Poland lagging behind. It is possible to observe strong increases in intra-industry trade with EU trading partners, and a decline in the strong comparative bias against sectors that require high levels of skills, research and development (R\&D) and, lately, capital. These Visegrad countries, compared to the Baltic states and the CIS, have progressed in expanding their exports with a higher degree of processing and value-added. ${ }^{31}$

One of the negative features of exclusion from the EU-orchestrated integration process is the very modest level of foreign investment, combined with low domestic in-

29 Moses, J.W., 2000

30 Dyker, D. "The Dynamic Impact of the Central-East European Economies of Accession to the European Union," mimeo, Brighton, School of European Studies, University of Sussex, 1999

31 Landesmann, M., 1995 and Dobrinsky, R. and Landesmann, M. 1998 
vestment potential. The patterns of foreign investment activity can be seen from the table below.

Table 8. Inward Flows of Foreign Direct Investment, billions of dollars ${ }^{32}$

\begin{tabular}{lccrrr}
\hline & $\begin{array}{c}1985-1995 \\
\text { (annual average) }\end{array}$ & 1997 & 1998 & 1999 & 2000 \\
\hline Belarus & 0.005 & 0.352 & 0.203 & 0.444 & 0.090 \\
Czech Republic & 0.540 & 1.300 & 3.718 & 6.324 & 4.595 \\
Poland & 0.768 & 4.908 & 6.365 & 7.270 & 10.000 \\
Russia & 0.415 & 6.638 & 2.761 & 3.309 & 2.704 \\
Ukraine & 0.075 & 0.624 & 0.743 & 0.496 & 0.595 \\
CEE & 3.2 & 19.2 & 21.0 & 23.2 & 25.4 \\
CEE and developing Europe & 3.3 & 20.8 & 22.3 & 25.1 & 26.8 \\
(excluding Malta) & & & & & 1075.0 \\
World & 180.3 & 477.9 & 692.5 & 1270.8 \\
\hline
\end{tabular}

Table 9. Inward Stocks of Foreign Direct Investment, billions of dollars ${ }^{33}$

\begin{tabular}{lccc}
\hline & 1995 & 1999 & 2000 \\
\hline Belarus & 0.050 & 1.153 & 1.243 \\
Czech Republic & 7.370 & 17.552 & 21.095 \\
Poland & 7.843 & 26.457 & 36.475 \\
Russia & 5.465 & 16.541 & 19.245 \\
Ukraine & 0.910 & 3.248 & 3.843 \\
CEE & 36.4 & 102.0 & 124.7 \\
CEE and developing Europe (excluding Malta) & 38.8 & 109.1 & 133.2 \\
World & 2937.5 & 5196.0 & 6314.3 \\
\hline
\end{tabular}

Foreign direct investment (FDI) in Belarus achieved a cumulative total of $\$ 1.243$ billion at the end of 2000 . This was less than 2.5 percent of the $\$ 50$ billion which, in 1996, the government announced was the amount of FDI needed by Belarus. ${ }^{34}$ Foreign capital has also taken no significant part in the privatization process. There is even a certain amount of hostility towards FDI, on the alleged ground that it leads to trade imbalances with the investors' countries - although experience has shown that, in 1998, companies with foreign capital had a share of 1.3 percent of employment, but accounted for 8 per cent of Belarus' exports (and, admittedly, 9.5 per cent of imports). ${ }^{35}$ For the last three years general investment dynamics have been negative, declining by 6 percent each year, which can mainly be attributed to the structural, and not cyclical problems. Among the reasons most often for why productive foreign investment continues to be inhibited are arbitrary law enforcement, bureaucratic corruption and security concerns. The direct consequence of this is that Belarusian economy will be further marginalized without the presence of foreign enterprises, which through FDI, joint ventures, or even OPT activities play an important role in the upward movement within the vertically differentiated structure of East-West production and trade relationships. In Belarus, which is dependent on borrowing of foreign technologies - 70 percent of all major technological processes originated from abroad ${ }^{36}$ - investment is still below the level required to maintain current production capacity. Belarus is simply eating away the economic potential it

32 UNCTAD, 2002

33 UNCTAD, 2002

34 Charman, K., 1999

35 Nuti, 2001

36 Belorusskaya Delovaya Gazeta, November 28, 2001, p. 32 
built in the past, falling further behind its neighbors, while its industrial development is militated by low indigenous capacity to create competitive products and the virtual absence of meaningful foreign investment.

A recurring conclusion from the analysis above is that in the light of the dynamic developments in CEE, the pathologies of the Belarusian economic system and the deficiencies of its one-dimensional regional orientation will become more salient when the republic's immediate neighbors become a part of the EU bloc, cemented by comprehensive trade and investment networks. In turn, this questions the competitive and modernizing potential of Belarusian-Russian integration. For Belarus, export orientation towards Russian has not yet generated substantial growth in wage levels or capital inflows. Real wage levels are at the moment bent on recovering earlier Soviet levels, regardless of productivity considerations, but still remain low and do not correspond to the basic costs of living. The level of Russian investment still remains unknown to the general public, with the exception of several large investment projects, e.g. building the "YamalEurope" pipeline, modernizing the Minsk-based brewery of the Baltika company and the participation of Russian companies in modernizing and privatizing the petrochemical industry.

Crisis in Russia has produced negative spillovers for Belarus, which suffered economic repercussions through a decline in external demand and contagion in the financial markets from the rupture of the payment and settlement systems in Moscow. Overall, economic activity slowed down substantially in the immediate aftermath of the Russian crisis, with output growth falling from about 8.5 percent in 1998 to 3.4 percent in 1999. ${ }^{37}$ Both exports and imports contracted substantially, resulting in a drop in the current account deficit from 6.1 percent of GDP in 1998 to 2.2 percent of GDP in 1999. Externally, exports to Russia, which accounted for more than 60 percent of total exports, fell during the second half of 1998 by 10 percent. Demand for Belarusian products was weak through 1999, showing signs of recovery only during the final quarter, with the revival of economic activity in Russia.

Another serious deficiency in the story of Russian-Belarusian integration is related to the fact that barter operations are still the dominant form of exchange, which last year accounted for more than 40 percent of mutual trade ${ }^{38}$ Barter has been supported by the invention of specific and non-transparent financial clearing schemes, aimed at retaining barter transactions despite rigorous state audit and control. Overall, barter operations in Russian-Belarusian trade emerged in the early 1990s, when some companies were granted special privileges to sustain trade between former Soviet Union republics. Further, price and VAT differentials have stimulated trade flows, while the use of barter operations allowed the extraction of profits even in unfavourable economic conditions. These mechanisms have not been combated in the course of creating a customs union between Belarus and Russia, which has nonetheless remained very much a paper union because of the existing tariff disparities between its members. For instance, Russia raised its import tariff on cars to protect the Russian automotive industry, while Belarus, which produces no cars, lowered its tariff, thus stimulating substantial trade in cars transiting from Europe through Belarus to Russia. In a similar fashion, Russian oil companies have managed to use Belarus' oil refineries to re-export oil, thus escaping Russian levies on oil exports. Unregistered export and import operations in trade in refrigerators, tires, computers, and microelectronic components are still significant so that it is not 
surprising that some groups lobbied vigorously both Belarusian and Russian governments to keep status quo in integration. The customs union has not developed any real institutions to resolve existing trade disputes, thus remaining a forum for high-level meeting with very low outcome. ${ }^{39}$ Moreover, Russia and Kazakhstan have accepted the goal of WTO membership, while Belarus has not moved further declarations that is supports this goal and at some point even plans to join in.

At the macro level, excessive subsidization has not resulted in the emergence of "national champions" in industry or agriculture that would be able to compete even at a CIS scale. Rather, it has slowed down the restructuring process and strengthened the monopolistic tendencies of large companies. As a result, national companies are becoming gradually crowded out by more successful competitors. Russian producers are gradually becoming more and more competitive in those sectors where Belarus has comparative advantage, such as machine-building, electronic and mechanical equipment, and textiles and footwear. In agriculture, Russian and some Ukrainian producers have managed to obtain significant shares of the Belarusian market by exporting food and beverages. For instance, in 2001 milk imports grew by 202 percent, grain by 204 percent, alcoholic drinks and beverages by 551 percent, according to data obtained from the Ministry of Statistics of the Republic of Belarus. Belarusian producers have demanded, albeit unsuccessfully, protectionist policies to defend themselves from the penetration of cheaper Russian and Ukrainian imports. Overall, foreign trade with Russia in value terms dropped by 1 percent, and price level of export and imports decreased by 4.4. percent and 14.5 percent on average, respectively. ${ }^{40}$ Nevertheless, for most commentators, close ties with Russia allow Belarus to import necessary imports cheaply. This has not prevented enterprises from making losses, while the level of profitability has dropped down to a maximum of 15 percent. The banking sector remains closed to the penetration of more dynamic Russian banks; however, few banks have been created to finance operations between the two countries.

In general, monetary integration between Belarus and Russia is one of the central, and at the same time recurrent, themes very often invoked in both political rhetoric and economic analysis. The record of initiatives related to the introduction of a single currency is full of promises which have not come into being. The intention to establish monetary union between Belarus and Russia was first expressed in 1993 - shortly after the break-up of the Soviet Union - when the two countries drew up an agreement to establish a joint monetary system. The process of monetary integration was intensified in 1996 and 1997 when several treaties established "economic union." The declaration of the countries' intent to implement a monetary union was signed in 1998 in Minsk. At the end of 2000 , as a step toward this monetary union, Belarus and Russia agreed to introduce a common currency and to adopt measures to create the appropriate conditions for the single currency. These agreements were ratified by the parliaments of Russia and Belarus in March and May 2001, respectively. However, there is still no agreement on the procedure for issuing the common currency.

It has been planned first that the common currency might resemble the transferable rouble, a unit of account used by the members of the Council for Mutual Economic Assistance (CMEA). Two decades ago, the transferable rouble was purely an accounting device to record trade imbalances arising in any period, for clearance in subsequent periods through planned trade transactions enshrined in bilateral trade agreements. By far,

39 Åslund, A., Garnett, S.W., and Olcott, M.B., 1999

40 Belorusskaya Gazeta, March 4, 2002, p. 8 
no clear suggestions have been made on how to resurrect this scheme and apply it to the case of Belarus and Russia. Another model takes its origin from an EU-type basket of currencies, gradually locked into a permanently fixed exchange rate between them. Given the relative size of population, national income, and mutual trade shares, Belarus could not expect a weight greater than 5 or 10 per cent in this basket, which also implies subsequent inferior positions in the currency management and the new joint monetary institutions. So far, endless negotiations over the fate of the single currency have resulted in agreement to adopt the Russian rouble as legal tender in 2005. From 2008, the two countries would introduce a new joint currency. But there is no guarantee that complex models can easily be implemented while the Russian rouble would circulate, which may, in turn, bring tough reforms for Belarusian economy similar to those encouraged by monetary integration between East and West Germany. It is also seen as a symbolic act since it will signify a truly supranational phase of integration.

\section{Addressing Existing Challenges and Pressures}

So far, the Belarusian economic system can be described as "market simulation," invoking some features of unsuccessful Hungarian reformist attempts to combat the dysfunctions of state socialism. ${ }^{41}$ Market simulation is a specific combination of overtly dominant state interference in the economic system with some bottom-up market transactions. Hence, this is a hybrid system emerging out of the old state socialist economy, and combining direct bureaucratic orders with selected market incentives. The state intervenes directly into the mechanics of economic transactions by manipulating the financial structure, producing policy errors, which probably have deeper causes than simple technical incompetence of the bureaucracy or the uncertain environment in which these decisions are being made. A forced marriage of the state and the market has triggered numerous attempts to exploit each other in an economically non-competitive, monopolistic, and even parasitic manner. This is also reflected in the widely accepted goal of Russian-Belarusian integration, which is very rarely questioned in terms of its efficiency. The whole corpus of integrationist rhetoric is reminiscent of "building socialism;" it might last for decades and finally end in absolutely nothing.

The explanation of why Belarus has decided to stick to such a developmental model lies in the nature of its division of labor with the former Soviet Union. Belarus had mainly specialized in assembling finished products out of components provided by the rest of the Soviet Union. As in the other state socialist countries, the industrialization of Belarusian SSR in the post-war period was defined by a growth strategy based on industrial expansion, i.e. by the location in the region of exogenous "branch plants" as a part of value chains administered by Soviet bureaucrats. The republic had been converted into the Soviet "assembly shop." Consequently, restructuring tasks were probably easier, because the equipment and labor involved in the assembly of components must have been less specific and easier to re-deploy or at any rate less than that involved in vertically integrated production. Moreover, long-standing complementarities of Russian and Belarusian production structures created a favorable background for deciding to keep them together during the post-socialist reformist phase. But the republic has not managed to get rid of the path-dependency in its industrial development. The Belarusian

41 Kornai, J., 1990 
economy has remained locked in to a mode of production replete with inefficiencies and rigidities associated with state socialist patterns of accumulation. This is incompatible with the conditions generated by relations of hierarchy and competition that are taken to be the essence of the European, and world, markets. Industrial policies, which have all the overtones of mercantilism and neo-corporatism, are becoming gradually obsolete because there is a great danger of every industry being labelled "strategic" whereas the number of strategic industries is really very small, especially when it is taken into account that subsidiaries of foreign companies may create indigenous capacities.

One of the principal analytical as well as policy-making questions is whether Belarusian economic model can be sustained in the medium to long run. The initial recovery has been achieved relatively easily because it relied on old production linkages. Even in 2000-2001 export growth, while slowing, has been achieved in the country's traditional industries, such as textiles and fibres, machinery, refrigerators, TV sets, vehicles and cement. They all were the pillars of the old Soviet production systems, but will not continue to have a quasi-monopolistic position in the region. It is rather doubtful whether this situation can be prolonged, at least without any difficulties. One of the key reasons is that higher levels than previously attained and/or new structures require a more flexible, market-oriented mechanism of signals and incentives. Even now, these industries are losing competitiveness since the Russian market has become more mature, thus demanding better quality and cheaper goods. Very roughly speaking, the Belarusian economy should somehow learn what Western societies experienced in the wake of the crisis of the Fordist accumulation regime in the early 1970s. In order to cope with increased competition and volatility in markets, Fordist firms were forced to revise their organizational structure and search for more flexible techno-organizational solutions. The disruption of Fordism was precisely the crisis of inflexible mass production, which was gradually replaced by new, more efficient technology (increased automation and informatization), reorganization of production and management, and, crucially, introduction of flexibility - in the use of machinery, labour and in the organization of the production process itself. The final say is left to the government, which should choose the optimal combination of state and market in the course of transformation.

But national governments do not operate in the vacuum, and hence we can assume that the external setting can influence the decisions of domestic actors. In the Belarusian context, this raises the question of the degree of external influence most likely induced by EU expansion further east and/or the reform process in Russia.

Consider the possible implications of EU eastward enlargement first. According to the policy document "The Concept of Responsible Partnership," adopted by the Belarusian Ministry of Foreign Affairs, the EU is seen as an important partner in economic relations. The EU enlargement process is treated positively by the Ministry's officials because it may shift the center of economic gravity further East, allowing Belarus to expand its foreign trade with the republic's immediate neighbors such as Poland and the Baltics. The rationale behind this is that the enlarged EU would no doubt remain the main trading partner in the developed world of the successor states to the former Soviet Union, including Belarus, for reasons of geography and culture. Indeed, the major channels of transmission through which EU enlargement will affect economic conditions in the neighboring countries runs via these countries' foreign trade and investment with the EU area. So far, these flows remain marginal for Belarus, with the exception of some private investment flows from German and Dutch firms. Partly, trade relations have been constrained by contingent protection, such as anti-dumping and safeguard actions applied to 
Belarusian textiles and potash fertilizers (although the latter has recently been relaxed by the EU). But the most serious impediment comes from the dysfunctions of the Belarusian economic system. This implies that Belarus may lose some shares of its non-CIS markets when more competitive economies of Poland and the Baltics become a part of the EU economy. At the political level, the EU has been consistent in practicing a rather isolationist policy since no agreement has been signed except the currently frozen Partnership and Cooperation Agreement (PCA). But such policies have not challenged the character of Belarusian polity and economy, which poses a new task for the EU to rethink its attitude and offer more flexible schemes for cooperation.

Second, the impact of Russian reforms might be much more perceptible compared to the implications of EU enlargement. Russia's influence, based not only on close political ties but also on market orientation, may be a decisive factor. Belarus' dependence on exports to Russia, and an agreement to introduce a single currency exposes it to the consequences of antagonisms and tensions emanating from the reform process in the Russian Federation. Importantly, from April 1, 2002 Belarus has agreed to abolish privileges granted to individual Belarusian enterprises and unify, albeit at a slow pace, the tax system. In practice, this implies that Belarusian enterprises will be forced to compete with relatively more advanced Russian companies on the basis offered by the Russian partner, although such painful adjustment will be smoothed by the adoption of the Russia's internal tariff schemes for electricity, gas, and transport. Therefore, a pragmatic turn in Russian foreign economic policy, aimed at creating favorable conditions for its own enterprises, can create pressures on the obsolete Belarusian economic model.

\section{Formulating Possible Scenarios and Policy Recommendations}

The discussion above leads to the formulation of three possible scenarios, differing in the degree of their feasibility. The starting point here is the understanding that the Belarusian government is now confronted with the choice between the risks of marginalizing its national polity and economy, and the opportunities arising from European integration, along with pressures stemming from modernization processes in Russia. Strategically, Belarus is confronted with a choice between maintaining a socialist-type, hybrid system and de novo construction of democratic and market-economy institutions, norms of conduct and behavioral patterns.

According to the first scenario, the Belarusian economy and polity could experience a worsening of the existing situation, and thus the policy focus would concentrate on keeping the obsolete industrial capacities and employment by offering insignificant and shrinking wages and welfare bonuses. Politically, the country would remain self-isolated from political cooperation with the EU bodies, which could lead to further marginalization of Belarus in the foreign policy arena. In this case, one could observe a continuation of the striking discrepancy between foreign policy priorities of Belarus and Russia, united in a single "union state" that requires the highest degree of policy coordination. Such a contrasting difference between foreign policy orientations of Belarus and Russia so far shows that despite the existence of a "union State" between them, there is in fact divergence of policy orientations in the political, economic, military and security fields. Economically, Belarus would be exposed to the disadvantages of disproportional orientation towards the CIS and especially Russian markets, which could be dangerous for a small open economy like Belarus. In a situation when meaningful foreign and domestic 
investment are virtually absent, the task of improving external competitiveness (e.g., upgrading exports goods in terms of quality, packaging, and marketing, and the use of international technical standards) would remain unresolved even in the longer term. This scenario is supported by the existing lobby in the government and high-ranking military officials both in Belarus and Russia, who think in old Cold War terms, as well as enterprise managers, who have access to the decision-making processes of resource distribution.

The second scenario projects that recent pragmatic turns in Russian foreign policy could be translated into a revision of existing relations between Belarus and Russia, which would in turn change the parameters of integration. In this case, Belarus would be incorporated into the Russian 'sphere of influence' and subjected to the Kremlin's political interests and pressures of Russian capital, which is currently trying to capture certain shares of the Belarusian market. Politically, keeping an isolated neighbor such as Belarus might be a good opportunity for the Russian president to maintain good relations with conservative social forces (such as communists and nationalists) operating in Russian political scene, and gain some popularity among electorate that supports these conservative forces. At the same time, the improved Russia-NATO and Russia-EU relations might be perceived as a pushing factor for changing a hostile attitude toward NATO and the OSCE. So far, cooperation between Russia and NATO has already undermined the traditionally unfriendly rhetoric of Belarusian authorities. Nonetheless, the recent pragmatic shift in the Russia's reformist attitude is not necessarily bad because this could influence the introduction of reforms, and thus force enterprises to learn how to compete in the relatively more mature Russian market. But there might be a serious disadvantage if Russian capital attempts to take control of strategic industries such as petrochemicals, energy production, and telecommunications. An additional aspect that needs to be mentioned here is related to the intensified economic cooperation between the EU and Russia, which is ultimately aimed at creating a free trade area (FTA) between them. If successful, Belarus could even become a member of this FTA. In this case, the similarity, or degree of overlap, in the trade structures of Belarus and Russia exporting to the EU and their markets provides an indication of the potential effects of free trade area. This scenario corresponds to the intentions of the Russian political and business elite, which is concerned about improving Russia's economic influence within the CIS, and is also supported by reform-oriented and pragmatic enterprise managers and ministerial technocrats.

The third scenario draws upon the opinion that the current Belarusian socioeconomic model has a finite time horizon. The Belarusian economy could gradually reach the limits of its developmental potential, and thus end up in an economic crisis that would require meaningful economic reforms. Because reforms would require foreign aid, certain measures aimed at democratization of the Belarusian society could be introduced with the help of either the Council of Europe or the OSCE. One of the first promising steps seems to be an international trade and finance liberalization strategy whose strength is that it requires very little institutional development. Idle capacity margins, first selectively, and then throughout the economy would be eroded so that new net investment would be required for sustained growth. In such a case, EU enlargement could produce strong positive externalities. Production networks, emerging in the course of EU enlargement, may reach further east, thus drawing Belarus into the regional industrial system. The potential for and speed of catching up is potentially high in all countries of the former Soviet bloc precisely because of the unbalanced nature of their inher- 
ited assets such as a good stock of engineering skills, but insufficient capabilities in design, marketing, and communication infrastructure. Given the current complex character of EU enlargement and its modernizing potential, it could be argued that Belarus needs to avoid agreements within the CIS that would discourage its participation in non-CIS markets. Trade and investment contacts with Western markets would offer Belarus access to the technology needed to upgrade its industrial base. This scenario generally reflects the aspirations of progressive social forces in Belarus, such as the nationaldemocratic opposition and trade unions.

It is impossible to predict which scenario will gain a momentum in the future, but it is certain that the EU should reserve room for action in any case. What should one count on when thinking about policy measures that could break the vicious circle of conflicts and misunderstandings? First of all, the EU should conceptually rethink its relationship with "awkward partners" now that the task is how to deal with considerable disparities on the EU's eastern borders. It needs to be recognized that policies of isolation have failed, which in turn requires new policy steps. Within the EU, this opinion has recently been advocated by France and Germany and opposed by Great Britain and the Netherlands. The development of a single, coordinated strategy needs to be placed at the heart of all policy proposals. It is of absolute importance to keep the tradition of the troika, this is the only way to efficiently limit unnecessary competition between the member states' governments and various international organisations. A common strategy towards Belarus is also necessary, because the degree of bureaucratization is high and various policy actions taken by different EU bodies could easily fall into the Belarusian bureaucratic nets and thus be undermined.

In an era of globalized and open borders, foreign policy is no longer dictated by a political elite from above. Rather, it incorporates the activities of a number of other actors, or, more broadly, social forces, which shape public attitudes and maintain an archipelago of contacts at a multiplicity of levels: government agencies, local selfgovernment, NGOs, educational units and individuals. Accordingly, NGOs could play a crucial role in expanding and maintaining those contacts because they are increasingly operating on a transnational scale. The EU should look for progressive, reform-oriented domestic social forces, located in the realm of civil society, and support them. The development of a strong civil society, which shares the values and beliefs of EU member states, is as vital to Belarus' integration into European structures as the development of sound market economy mechanisms and stable public institutions. The emergence of such norms, values and beliefs, and their entrenchment into the webs of civil society, are always long-term processes. Intensifying exchanges between various NGOs and their Western European counterparts can be a useful tool to built a transnational coalition of social forces committed to a more liberal and democratic way of development. It also will help to secure the voice of a broader democratic coalition created before the presidential elections. Seminars and conferences, where both authorities and other parties are represented are the instruments which could create the background necessary for dialogue and change.

More concretely, one possible policy action is to extend a selective approach, which at present means working-level cooperation at the ministerial level or below. At the level of intergovernmental cooperation, the Belarusian Chamber of Representatives would continue its attempts at restore its status at the PACE. If achieved, this return would signify a first step in a return to normality in intergovernmental relations between Belarus and the EU. Thus far, this goal has not been achieved, so it could serve as both an enabling and constraining factor for Belarus. Bilateral initiatives at the ministerial level 
should be put in place, because they cover various technical aspects of cooperation. Lower-level cooperation should not be a substitute for a single strategy. Changes to the electoral law should remain on the policy agenda and be monitored by the PA of OSCE so that elections to both the Belarusian and the union state parliament, planned for 2003, could be perceived as free and fair.

Another area of cooperation is with Belarus' immediate neighbors. In 1994 Belarus acquired associate member status in the Central European Initiative, which focuses on transport, energy, ecology, cultural, and educational affairs. The development of contacts in this direction might be a promising area. As for possible EU aid, the problem is that industrial aid would almost certainly be diverted, to one degree or another, to the existing industrial structures and employment patterns, in effect to help maintain the system of soft budget constraints. There may be an argument for extending specific forms of aid in the area of infrastructure. Perhaps even more important, educational and technical aid could be organized in specific programs to remove the need for indefinite recurrent financial commitments. This definitely points to resuming the TACIS program, which was cut last year. Such programs would address the underlying problem of how to create new know-how complexes and ultimately helping Belarus to generate its own innovatory dynamism. Not only the EU, but also the international financial institutions should have a greater role to play in the development of the Belarusian economy by catalyzing investments in selected priority areas such as healthcare, environmental protection or infrastructure. In so doing, they would address the critical medium- and longterm problem of how to bring about Belarus' participation in the European economy. It is important to know that economic cooperation with the enlarged EU can not be either planned or ordered. The deals would rather be made on the basis of profitability, irrespective of whether they involve the EU itself, its future members from CEE and the Baltics, or indeed fellow CIS members. The final say thus remains with the national government, which should put in place policies and institutions aimed at boosting meaningful domestic economic activity; otherwise, potential and outcomes are bound to differ substantially.

\section{Bibliography}

Åslund, A., Garnett, S.W., and Olcott, M.B. Getting It Wrong: Regional Co-operation and the Commonwealth of Independent States, Washington, D.C., Carnegie Endowment for International Peace, 1999

Boratynski, J. \& Gromadzki, G. "The Half-Open Door: The Eastern Border of the Enlarged European Union," On the Future of Europe, Policy Paper 2, Stephan Bathory Foundation, Warsaw, March 2001 ,

Belorusskaya Delovaya Gazeta, November 28, 2001

Belorusskaya Gazeta, October 15, 2001

Belorusskaya Gazeta, November 16, 2001

Belorusskaya Gazeta, March 4, 2002

Belorusskaya Gazeta, April 29, 2002

Belorusskaya Gazeta, May 27, 2002

Charman, K., "Belarusian Economic Trends," TACIS Quarterly Report, No. 2, 1999

Dyker, D. "The Dynamic Impact of the Central-East European Economies of Accession to the European Union," mimeo, Brighton, School of European Studies, University of Sussex, 1999

EBRD, The Transition Report 1999: Ten Years of Transition, London, Oxford University Press, 1999

EBRD, The Transition Report 2000/2001, London, Oxford University Press, 2001 
IMF, Republic of Belarus: Recent Economic Developments and Selected Issues, IMF Staff Country Report, No. 00/153, Washington, DC, IMF, 2000

IMF, Republic of Belarus: Recent Economic Developments, IMF Staff Country Report, No. 99/143, Washington, D.C.,IMF, 1999

IMF, Republic of Belarus: Selected Issues, IMF Staff Country Report, No. 02/22, Washington, D.C., IMF, 2002

IMF, World Economic Outlook 2001, Washington D.C., IMF, May 2001

Karaganov, S. "Russia and the Slav Vicinity," in: Russia and Europe: The Emerging Security Agenda, Baranovsky, V. (ed.) Oxford, Oxford University Press, 1997

Kornai, J., The Socialist Economy. The Political Economy of Communism, Princeton, Princeton University Press, 1990

Landesmann, M. "The Pattern of East-West European Integration: Cost Structures and Patterns of Specialisation," in: Transforming Economies and European Integration, Dobrinsky, R. and Landesmann, M. (eds.), Aldershot, Edward Elgar, 1995

Landesmann, M. "The Shape of the New Europe: Vertical Product Differentiation, Wage and Productivity Hierarchies," BRIE Working Paper, No. 104, 1998

Moses, J.W. OPEN States in the Global Economy. The Political Economy of Small-States Macroeconomic Management, London, Macmillan, 2000

Nuti, M., "Belarus: A Command Economy Without Central Planning," Russian and East European Finance and Trade, vol. 36, no. 4, July-August 2000, pp. 45-79

Statistical Bulletin of the Ministry of Statistic and Analysis of the Republic of Belarus, Minsk, July 2001

UN ECE, World Economic Situation and Prospects, Geneva, United Nations, 2002

UNCTAD, World Investment Report 2001: Promoting Linkages, Geneva, United Nations, 2002

Zlotnikov, L. "Prichinyi Economicheskogo Krizisa," in: Economicheskaya Politika: Analiz i Perspectiva, L. Zlotnikov \& V. Shlyindikov (eds.), Minsk, Bestprint, 1999

Zysman, J. \& Schwartz, A. "Introduction. Enlarging Europe: The Industrial Foundations of a New Political Reality," in: Enlarging Europe: The Industrial Foundations of a New Political Reality Zysman, J. \& Schwartz, A. (eds.), Berkeley, CA, A BRIE/Kreisky Forum Project, 1998

\section{A List of Relevant Publications on and Internet Links to the Topic}

http://www.batory.org.pl/ftp/program/europejski/Raport_Schengen_ang.rtf

Centre for Eastern Studies. "Belarus in the World Arms Market," Materials CES, November 29, 2001, http://www.osw.waw.pl/english/eramym.htm

Grabbe, H. "The Effects of EU Enlargement on the Countries Left Outside," Economist Intelligence Unit Report, June 2001

Löwenhardt, J., Hill, R.J., and Light, M. "A Wider Europe: The View from Minsk and Chisinau," International Affairs (London), Vol. 77, No.3, July 2001, pp. 605-620

Naumczuk, A., Mironowicz, E., Kazanecki, P., and Gromadzki, G. "The Forgotten Neighbour - Belarus in the Context of EU Eastern Enlargement," On the Future of Europe, Policy Paper 4, Stephan Bathory Foundation, Warsaw, September 2001,

http://www.batory.org.pl/ftp/program/europejski/rap4en.rtf

Rontoyanni, C. A Russo-Belarusian "Union State": A Defensive Response to Western Enlargement?, University of Glasgow Working Paper, No. 10/00, September 2000, http://www.one-europe.ac. uk/pdf/W10Clelia.PDF

Ulahovich, V., "Relationships between the EU and the Republic of Belarus: Conditions and Prospects for Development," Ekonomicheskii Vestnik, Vol. 1, No. 2, 2001, pp. 336-347, http://www.ipm. by/pdf/Ulahovich.pdf

Kiryl Haiduk holds a degree in economic theory from the Belarus State University (1998) and a Master of Arts in Contemporary European Studies from the University of Sussex at Brighton (UK). After graduating from Sussex (2000), he has been affiliated 
with the Centre for Policy Studies, Open Society Institute, Budapest, where he took part in the research project on economic policy implications of the EU eastward expansion for Belarus and Russia. Recently, he has joined the International Centre for Social and Economic Policy, opened by the International Labour Organisation in collaboration with the Federation of Trade Unions of Belarus. Mr. Haiduk is also teaching part-time at the Faculty of Economics of European Humanities University in Minsk. His principal research interests are the economics of transition and international political economy, theory and practice of regional integration, and specifically EU Eastward enlargement. Mr. Haiduk has written several articles on international economic relations and transition economics. The author is currently at the final year of post-graduate studies at the Belarus State University, Faculty of Economics, where he is working on both a doctoral dissertation and a monograph devoted to economic integration in East-Central Europe.

Among his recent publications are "Globalisation, Regional Integration and Economic Development" in a textbook on Contemporary Economic Theory (forthcoming), and "Exploring EU Eastward Enlargement Problematique: A Comprehensive Conceptual Review" in the national academic journal called Economic Bulletin. 